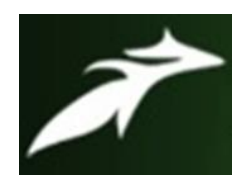

Temsukala Lemtor et al, International Journal of Advances in Agricultural Science and Technology,

Vol.8 Issue.9, September-2021, pg. 136-141

ISSN: 2348-1358

Impact Factor: 6.057

NAAS Rating: 3.77

\title{
Study the Working Conditions of Ao Naga Tribal Women Engaged in Different Farming Activities at Tuli Block of Mokokchung, Nagaland
}

\author{
Temsukala Lemtor ${ }^{1}$; Dr. Syed H. Mazhar ${ }^{2}$; Dr. Jahanara ${ }^{3}$ \\ ${ }^{1}$ M.Sc. Ag. (Agricultural Extension and Communication), SHUATS (Prayagraj) \\ ${ }^{2}$ Associate Professor, Dept. of Agriculture Extension and Communication, SHUATS (Prayagraj) \\ ${ }^{3}$ Professor and Head, Dept. of Agriculture Extension and Communication, SHUATS (Prayagraj) \\ Author's e-mail: Temsuman8@gmail.com \\ DOI: 10.47856/ijaast.2021.v08i9.015
}

\begin{abstract}
This study has been conducted to find out the working conditions of Ao Naga tribal women in different farming activities in the district of Mokokchung. The aforementioned study was conducted in Tuli Block at Mokokchung district in the year 2021. A descriptive research designed was applied for this study. The primary data was collected from 120 respondents by personal interview method using pre-structured interview schedule. After the analysis of the data it was observed that, maximum number of the respondents were having medium level of extension contact and a medium level percentage was found in regards to the attitude of the respondents.
\end{abstract}

Keywords: Socio economic, Attitude, Tribal women farmers

\section{Introduction:}

Agriculture is the presiding occupation in Nagaland, in both employment and income source; it is the main stay of economy in the state and the traditional form of farming had been in practice by the Nagas since time immemorial. In this process they have developed skills and ideas on how best to grow their crops and enhance its productivity.

In the context of Nagaland, Women are playing a significant and crucial role in agricultural operations along with household chores through traditional forest based agricultural practices, Jhum and terrace agriculture, homestead gardening, seed saving and sharing. About $65.2 \%$ and $7.3 \%$ of female workers in rural Nagaland constitute the cultivators and agricultural workers respectively, outnumbering male cultivators (47.4\%) and male agricultural labourers. (Morung Express, 2019)

However, women farmers remain invisible in their identity as farmers. Despite progress on many fronts, due to structural barriers and discriminatory social norms, they lack equal access to and control of productive resources and assets in rural areas - their voice, agency and representation in the political and economic spheres hindered. Access to infrastructure, services and social protection also remains a huge challenge. 


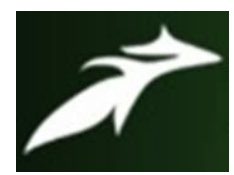

Temsukala Lemtor et al, International Journal of Advances in Agricultural Science and Technology, Vol.8 Issue.9, September-2021, pg. 136-141

\section{Research Method:}

Descriptive research design was used for the present study. Descriptive research design describes the characteristics of the population or phenomenon that is being studied. It focuses more on the "what" of the research subject rather than the "why" of the research subject. The major purpose of descriptive research is description of the state of affairs as it exists at present. Primary data was collected through personal interview with the help of pre-tested interview schedule. Secondary data was collected from available reports, journals etc.

\section{Objectives of the study:}

1. To access the socio-economic status of the respondents.

2. To know the attitude of Ao Naga Tribal Women towards the working condition in different farming activities.

\section{Results and Discussion:}

Table 1. Socio-economic profile of the respondents.

\begin{tabular}{|c|c|c|c|c|}
\hline S.no & $\begin{array}{l}\text { Independent } \\
\text { Variables }\end{array}$ & Category & Frequency & Percentage \\
\hline \multirow[t]{3}{*}{1.} & \multirow[t]{3}{*}{ Age } & Young (20-35) & 33 & 27.00 \\
\hline & & Middle Age (36-55) & 55 & 46.00 \\
\hline & & Old (Above 55) & 32 & 27.00 \\
\hline \multirow[t]{6}{*}{2.} & \multirow[t]{6}{*}{ Education } & Illiterate & 40 & 33.00 \\
\hline & & Primary & 30 & 25.00 \\
\hline & & Secondary School & 24 & 20.00 \\
\hline & & High School & 19 & 16.00 \\
\hline & & Higher Secondary & 7 & 6.00 \\
\hline & & Graduate and above & Nil & Nil \\
\hline \multirow[t]{2}{*}{3.} & \multirow[t]{2}{*}{ Marital Status } & Married & 110 & 92.00 \\
\hline & & Unmarried & 10 & 8.00 \\
\hline
\end{tabular}




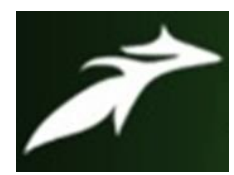

Temsukala Lemtor et al, International Journal of Advances in Agricultural Science and Technology, Vol.8 Issue.9, September-2021, pg. 136-141

ISSN: 2348-1358

Impact Factor: 6.057

NAAS Rating: 3.77

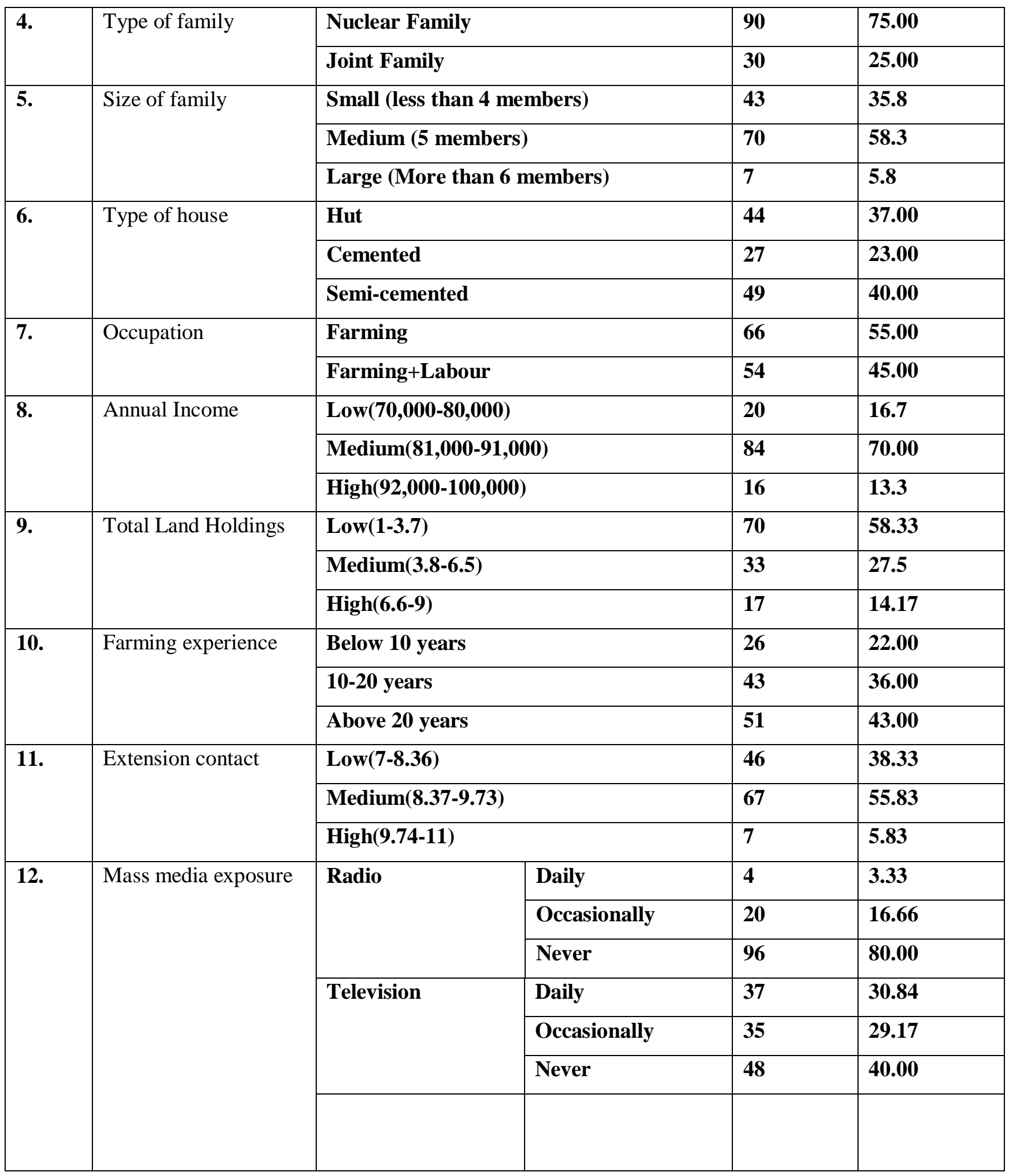




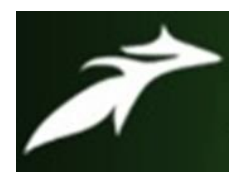

Temsukala Lemtor et al, International Journal of Advances in Agricultural Science and Technology, Vol.8 Issue.9, September-2021, pg. 136-141

ISSN: 2348-1358

Impact Factor: 6.057

NAAS Rating: 3.77

\begin{tabular}{|c|c|c|c|c|c|}
\hline & & \multirow[t]{3}{*}{ Newspaper } & Daily & 12 & 10.00 \\
\hline & & & Occasionally & 49 & 40.84 \\
\hline & & & Never & 59 & 49.17 \\
\hline & & \multirow[t]{3}{*}{ Mobile } & Daily & 93 & 77.5 \\
\hline & & & Occasionally & 10 & 8.30 \\
\hline & & & Never & 17 & 14.17 \\
\hline & & \multirow[t]{3}{*}{ Computer/internet } & Daily & 2 & 1.60 \\
\hline & & & Occasionally & 37 & 30.80 \\
\hline & & & Never & 81 & 67.60 \\
\hline & & \multirow[t]{3}{*}{ Magazines/Journals } & Daily & $\mathbf{0}$ & $\mathbf{0}$ \\
\hline & & & Occasionally & 5 & 4.10 \\
\hline & & & Never & 115 & 95.90 \\
\hline \multirow[t]{12}{*}{13.} & \multirow{12}{*}{$\begin{array}{l}\text { Sources of } \\
\text { information }\end{array}$} & \multirow{3}{*}{$\begin{array}{l}\text { Progressive } \\
\text { Farmers }\end{array}$} & Frequently & 80 & 66.67 \\
\hline & & & Sometimes & 25 & 20.84 \\
\hline & & & Rarely & 15 & 12.50 \\
\hline & & \multirow[t]{3}{*}{ Neighbours } & Frequently & 35 & 29.17 \\
\hline & & & Sometimes & 65 & 54.17 \\
\hline & & & Rarely & 20 & 16.67 \\
\hline & & \multirow[t]{3}{*}{ Relatives } & Frequently & 15 & 12.50 \\
\hline & & & Sometimes & 77 & 64.17 \\
\hline & & & Rarely & 28 & 23.34 \\
\hline & & \multirow[t]{3}{*}{ Friends } & Frequently & 67 & 55.84 \\
\hline & & & Sometimes & 47 & 39.17 \\
\hline & & & Rarely & 6 & 5.00 \\
\hline
\end{tabular}

From Table 1, it is found that majority of the respondents belong to middle age group. Majority of the respondents were Illiterate, majority of the women were married, majority of the families were nuclear families and majority had about 5 family members. 


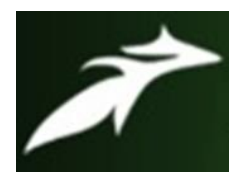

Temsukala Lemtor et al, International Journal of Advances in Agricultural Science and Technology, Vol.8 Issue.9, September-2021, pg. 136-141

Majority of the respondents have semi-cemented house. Majority of the respondents earn their income only through farming. Most of the respondents were having medium level of income. Majority had low land holdings and majority had farming experience below 10 years. Maximum number of respondents were having medium level of extension contact.

Majority of the respondents never use the radio, majority never use the television, majority never read the newspaper, and majority use mobile phone on a daily basis. It was found that majority never use the computer and never read journals or magazines.

It was also found that majority of the respondents get their source of information from frequent interaction with the progressive farmers, majority frequently interact with their neighbours, majority sometimes interact with their relatives and majority of the respondents frequently interact with their friends.

Table 2. Distribution of the respondents based on attitude towards the working condition of Ao Naga tribal women in different farming activities.

\begin{tabular}{|c|l|c|c|}
\hline Sl. No. & Category & Frequency & Percentage \\
\hline 1. & Low $(<24)$ & 18 & 15 \\
\hline 2. & Medium (24-30) & $\mathbf{7 9}$ & $\mathbf{6 5 . 8}$ \\
\hline 3. & High $(>30)$ & 23 & 9.7 \\
\hline & Total & 120 & 100 \\
\hline
\end{tabular}

From the above table 2, it is found that the level of attitude of Ao Naga tribal women towards the working condition in different farming activities is medium. 


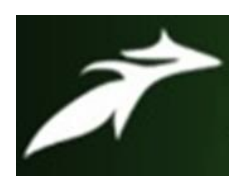

Temsukala Lemtor et al, International Journal of Advances in Agricultural Science and Technology, Vol.8 Issue.9, September-2021, pg. 136-141

ISSN: 2348-1358

Impact Factor: 6.057

NAAS Rating: 3.77

\section{Conclusion:}

It is concluded from this study that the Ao Naga tribal women in the area are hardworking and their livelihood depends on agriculture. It is therefore concluded that majority of the respondents were middle aged people, illiterate and married. Most of the respondents had a nuclear family and most of them lived in semi-cemented house. Majority of the respondents had agriculture as their occupation and majority of them had farming experiences of above 20 years. A large number of the respondents had medium level of income. Most of the respondents also had social contacts with ATMA. Majority of the respondents were having medium level of attitude towards the working condition in different farming activities.

The level of attitude was medium due to lack of education and less extension activities in the area. Extension activities and various developmental programmes are needed to improve the attitude and skills of the tribal women in the area.

\section{References}

[1]. Ansari, M.A. and Jantwa, V. (2019) "Attitude of Farm Women towards Agriculture Extension Services: A Study in Kumaon Region of Uttarakhand" Anthropologist, 38(1-3): (9-16)

[2]. Mohanta, R. (2017), "Participation of Tribal Women in Agriculture", International Journal of Science, Environment ISSN and Technology, Vol. 6, (1), Pp. 745 - 750.

[3]. Saindas, P. (2013) "Role performance of tribal women in agriculture", M.Sc(Agri extension) Thesis, Dr Panjabrao Deshmukh Krishi Vidhyapeeth, Akola.

[4]. Sanchana, P.C. (2015) "Analysis of livelihood of tribal women: The case of Palakkad District, M.Sc(Ag) thesis, College of Agriculture, Vellayani, Thiruvananthapuram, Kerala, India.

[5]. Solo,V. and Kikhi, K., (2020) "An overview of the farming systems in Nagaland" Journal of Pharmacognosy and Phytochemistry, Vol 10(1): 238-243

[6]. The morung express (2019) "Women constitute $70 \%$ of agri sector workforce in Nagaland", Vol. 15(283) pp.2 